\title{
Prevalence of developmental dental hard-tissue anomalies and association with caries and oral hygiene status of children in Southwestern, Nigeria
}

\author{
Bamidele O. Popoola ${ }^{1,4^{*}}$, Nneka Onyejaka ${ }^{2}$ and Morenike O. Folayan ${ }^{3}$
}

\begin{abstract}
Background: Developmental dental hard tissue anomalies are often associated with oral health problems. This study determined the clinical prevalence of developmental dental hard tissue anomalies in the permanent dentition of children resident in southwestern Nigeria and its association with dental caries and poor oral hygiene status.

Methods: This was a cross-sectional study recruiting 1565 school children, 12 to 15 year old attending schools in Ibadan, Oyo State and Ile-Ife, Osun State. All eligible study participants had oral examinations conducted to determine presence of developmental hard dental tissue anomalies, caries and oral hygiene status. The prevalence of developmental dental hard tissue anomalies was determined. Logistic Poisson regression was used to determine the association of between developmental dental hard tissue anomalies, caries and oral hygiene status.

Results: Only 65 (4.2 \%) children had clinically diagnosed developmental dental hard tissue anomalies. The most prevalent anomaly was enamel hypoplasia $(2.2 \%)$. More females $(p=0.003)$ and more children with middle socioeconomic class $(p=0.001)$ had enamel hypoplasia. The probability of having poor oral hygiene was significantly increased for children with developmental dental anomalies (APR: 0.07; 95 \% Cl: $0.03-0.12$; $p=0.002$ ). The probability of having caries was insignificantly increased for children with developmental dental hard tissue anomalies (APR: 0.005; $95 \% \mathrm{Cl}:-0.03-0.04 ; p=0.08$ ).

Conclusion: The most prevalence clinically detectable developmental dental hard tissue anomalies for the study population was enamel hypoplasia. The presence of developmental dental hard tissue anomalies significantly increased the chances of having poor oral hygiene but not caries. Further studies are required to understand if poor oral hygiene is associated with dental caries in children with developmental dental hard tissue anomalies.
\end{abstract}

Keywords: Developmental, Dental hard-tissue, Anomalies, Dental caries, Oral hygiene

\section{Background}

Developmental dental hard tissue anomalies cover a range of anomalies that affect tooth number, shape, size and tooth structures. Its prevalence varies between countries and tribes. For example congenitally missing teeth is the most prevalent dental anomaly found in Indians [1, 2], Saudi Arabians [3], Turkish [4] and Norwegian children

\footnotetext{
* Correspondence: olubukolap@gmail.com

'Department of Child Oral Health, College of Medicine, University of Ibadan, Oyo State, Nigeria

${ }^{4}$ Department of Child Oral Health, Faculty of Dentistry, College of Medicine, University of Ibadan, Oyo State, Nigeria

Full list of author information is available at the end of the article
}

[5]. In Nigeria however, enamel hypoplasia is the most common dental anomaly in children while hypodontia is a rare clinical feature $[6,7]$.

A number of these anomalies can be diagnosed clinically and prompt management is important for a number of reasons: they are associated with oral health problems including malocclusion [8], caries [9] poor oral hygiene [10] and aesthetic concerns [11]. They could also predispose to functional problems and other diseases [1]. In addition, the developmental dental hard tissue anomalies may be associated with syndromes, especially when the anomalies are multiple $[12,13]$. 
Past studies have demonstrated an association between developmental dental hard tissue anomalies and poor oral health status: developmental enamel defects are associated with increased risk for caries [14-16]; and supernumerary teeth can also lead to gingivitis and caries due to plaque retention in inaccessible areas [17]. Hypodontia and hyperdontia are both associated with malocclusion [18] and malocclusion increases the risk for caries [19] and poor oral hygiene [20]. These associated oral health disorders could impact negatively on the quality of lives of affected persons [7, 21].

However, little is known about how developmental dental hard tissue anomalies constitute a risk factor for dental caries and poor oral hygiene in the study population where the use of fluoride containing dentifrices is high [22], caries prevalence and severity is low [23] and the proportion of children with poor oral hygiene is low [24]. This study therefore determined the association of clinical presence of developmental dental hard tissue anomalies, caries and poor oral hygiene. This study also builds on a prior report that determined the clinical prevalence of developmental dental hard tissue anomalies in the mixed dentition [7]: this study determined the clinical prevalence of developmental dental hard tissue anomalies in the permanent dentition in Southwestern Nigeria.

\section{Methods}

\section{Study setting}

This was a cross-sectional study conducted in secondary schools in two of the six states in South-western Nigeria. The States are Osun and Oyo States. The states were selected based on the ease of access of the study team to school pupils (the institutions of the investigators are located within the states). To ensure access to children with diverse socioeconomic background, Ibadan (an urban region in Oyo State) and Ile-Ife (a suburban region in Osun State) were considered appropriate study sites.

\section{Sampling procedure}

In each state, pupils from secondary schools in the five local government areas that make up Ibadan metropolis and one of the four local government areas that make up Ile-Ife were recruited using a multi-prong approach.

The sample was first proportionally distributed amongst the Local Government Areas and then proportionately distributed between the private and public schools in the Local Government Areas. Each public and private secondary school from which participants emerged were selected from the sampling frame based on a constant of $K=10$ (The constant $\mathrm{K}$ was chosen to be 10 based on the least number of schools in a local government such that every 10th school in each local government was selected for the study). For this study, proportionate representation of private and public schools was important so as to ensure representation of children from all socio-economic strata in the study sample. Usually children from the high socioeconomic strata attend private schools and those from the low socioeconomic strata attend public schools.

In each school, the classes with the highest number of pupils who met the age eligibility criteria were selected for the study. All children within the age range for the study were recruited into the study. Recruitment in each school continued till the sample size for the school was reached.

\section{Study population}

The study population included all children who met the following criteria: 12 years to 15 years of age, parental consent for study participation was obtained, student assent for study participation was obtained. The age 12 years was selected as the minimum age since mean age of eruption of the second permanent molar in Nigerian children is approximately 12 years [25].

\section{Sample size}

The sample size for the study was estimated by use of the Leslie Fischer's formula [26] for study populations of more than 10,000 at a $95 \%$ confidence level with $26.6 \%$ prevalence of developmental dental hard tissue anomalies [7]. It was determined that it would be necessary to examine a minimum of 303 children per State for the study to be powered enough to determine the prevalence of developmental dental hard tissue anomalies in the region.

\section{Data collection}

Data was collected through personal interviews of study participants and conduct of oral examinations. Data was collected using the same structured questionnaire administered by Temilola et al. [7] in their study. The questionnaire elicited information on the child's sociodemographic characteristics (age, sex, and socioeconomic status). Socioeconomic status for the purpose of this study was obtained through a multiple item-scoring index combining the mother's level of education with the occupation of the father; each child was allocated to a social stratum I to $\mathrm{V}$, with social stratum $\mathrm{V}$ being the lowest. The social classification system has been well-tested and found valid and reliable for the Nigerian environment [27, 28]. Each child was classified as being in high socioeconomic class (strata 1 and II), middle socioeconomic class (strata III), and low socioeconomic class (strata IV and V).

All children eligible to participate in the study had an oral examination. A paediatric dentist conducted the clinical examination for study participants in Oyo and Osun States respectively. These dentists were conversant with normal and pathological dental features and both had more than 10 years of clinical practice experience. 
The children were examined under natural light while sitting on a chair. The teeth were examined wet and debris was removed with a piece of gauze when present.

\section{Developmental dental hard tissue anomalies}

All developmental dental hard tissue anomalies that were clinically observable were recorded. The diagnostic criteria for developmental dental hard tissue anomalies adopted by Temilola et al. [7] were used for this study. The developmental dental hard tissue anomalies diagnosed were talon cusp, microdontia, macrodontia, gemination, fusion, enamel hypoplasia, dens evaginatus, dens invaginatus, supernumerary, hypodontia, tooth transposition and notched incisor.

\section{Caries assessment}

The numbers of decayed, filled and missing teeth (DMFT) were noted for children with caries. The DMFT was determined based on the WHO Oral Health Survey methods [29]. The examination for dental caries was conducted with a sterile mouth mirror and dental caries explorer using natural light outdoors with the child seated on a chair. The examination of the teeth was done in an orderly manner from one tooth to another. Examination for dental caries included all surfaces.

To arrive at a DMFT score for an individual child, three values were determined: the number of teeth with carious lesions, the number of extracted teeth due to caries, and the number of teeth with fillings or crowns [30]. Where a missing tooth was identified, efforts was made to explore the reason for the lost tooth from the child and where possible, from the parent through a phone call placed through to seek clarification on reason for missing teeth. Only teeth extracted due to caries were recorded as missing. The number of carious, missing due to caries and filled teeth are summed together to give the DMFT score for each participant. For analysis purposes, caries was also classified as present or absent.

\section{Oral hygiene assessment}

The oral hygiene status was determined using the oral hygiene index (OHI-S) by Greene and Vermillion [31]. The OHI-S comprises debris and calculus scores on selected tooth surfaces. The following were the index teeth: the first molars but sometimes the second were used if the first molars were missing. The buccal surfaces of upper molars and the lingual surfaces of the lower molars were examined. In the anterior portion of the mouth, the labial surfaces of the upper right and the lower left central incisors were examined.

The debris and calculus scores were added and divided by the number of surfaces examined to give the OHI-S score as recommended. Oral hygiene was classified as good, fair, or poor when the score ranges were $0.0-1.2$, $1.3-3.0$, and $>3.0$, respectively.

\section{Standardization of examiners}

The two examiners are trained Paedodontists, practicing for a minimum of 10 years. They both undertook a series of calibration exercises to ensure the validity of their evaluations. The exercises was based on the protocol by Temilola et al. [7] for dental anomaly, the WHO criteria for the diagnosis of caries [30] and the OHI-S index described by Green and Vermillion [31]. The examiners had several sessions reviewing clinical photographs and repeated practices on examination of lesions, using clinical photographs. This training was followed by examination of live patients.

\section{Data analysis}

For ease of analysis, socioeconomic status in this study was regrouped into three levels: high (upper and upper middle classes), middle (middle class), and low (lower middle and lower classes). This categorization was used to test associations and for logistic regression analysis. This categorization of socioeconomic status was previously used by Folayan et al. [32]. Descriptive analysis was conducted to determine the prevalence of ECC in the study population for each age, each sex, and each socioeconomic stratum. The Pearson's Chi-squared test or Fisher's exact test was used to test associations between developmental dental hard tissue anomalies and (i) sex, (ii) age, (iii) socioeconomic status, (iv) presence of caries and (v) oral hygiene status. Multivariate logistic regression was also conducted using the Poisson regression analysis, to determine the association between presence of developmental dental hard tissue anomalies, caries and poor oral hygiene. The estimated coefficients, expressed as prevalence ratios (PRs), and their $95 \%$ confidence intervals were also calculated. Statistical analysis was done with Intercooled STATA (release 12). Simple proportions were computed. Statistical significance was inferred at $p<0.05$.

\section{Results}

One thousand, five hundred and sixty five children were recruited into the study. No child eligible to participate in the study refused study participation. Age, sex, and socioeconomic class of study participants recruited for the study are as shown in Table 1 . Sixty five (4.2\%) children had developmental dental hard tissue anomalies. Of the 65 children who had developmental dental hard tissue anomalies, none had two or more developmental dental hard tissue anomalies. There was no significant age $(p=0.46)$, sex $(p=0.44)$ and socio-economic $(p=0.48)$ difference in the proportion of children who had or did not have developmental dental hard tissue anomalies.

There was also no significant difference in the proportion of children with or without developmental dental 
Table 1 Socio-demographic profile of respondents with and without dental hard tissue anomalies $(N=1565)$

\begin{tabular}{|c|c|c|c|c|}
\hline Variables & Dental hard tissue anomaly present $(n=65)$ & Dental hard tissue anomaly absent $(n=1500)$ & Total $(N=1565)$ & $P$ value \\
\hline \multicolumn{5}{|l|}{ Sex } \\
\hline Male & $24(36.9 \%)$ & $627(41.8 \%)$ & $651(41.6)$ & \multirow[t]{2}{*}{0.44} \\
\hline Female & $41(63.1 \%)$ & $873(58.2 \%)$ & $914(58.4 \%)$ & \\
\hline \multicolumn{5}{|l|}{ Age } \\
\hline 12 years & $25(38.5 \%)$ & $456(30.4 \%)$ & $481(30.7 \%)$ & \multirow[t]{4}{*}{0.46} \\
\hline 13 years & $18(27.7 \%)$ & $498(33.2 \%)$ & $516(33.0 \%)$ & \\
\hline 14 years & $13(20.0 \%)$ & $366(24.4 \%)$ & $379(24.2 \%)$ & \\
\hline 15 years & $9(13.8 \%)$ & $180(12.0 \%)$ & $189(12.1 \%)$ & \\
\hline \multicolumn{5}{|c|}{ Socio-economic status } \\
\hline Low & $21(32.3 \%)$ & $499(33.3 \%)$ & $520(33.2 \%)$ & \multirow[t]{3}{*}{0.48} \\
\hline Middle & $32(49.2 \%)$ & 640 (42.7 \%) & $672(43.0 \%)$ & \\
\hline High & $12(18.5 \%)$ & $361(24.0 \%)$ & $373(23.8 \%)$ & \\
\hline \multicolumn{5}{|l|}{ Caries status } \\
\hline Present & $8(12.3 \%)$ & $165(11.0 \%)$ & $173(11.0 \%)$ & \multirow[t]{2}{*}{0.70} \\
\hline Absent & $57(87.7 \%)$ & 1335 (89.0 \%) & 1392 (89.0 \%) & \\
\hline \multicolumn{5}{|c|}{ Oral hygiene status } \\
\hline Good & $10(15.4 \%)$ & 362 (24.1 \%) & 372 (23.8 \%) & \multirow[t]{3}{*}{0.03} \\
\hline Fair & $44(67.7 \%)$ & 1009 (67.3 \%) & 1053 (67.3 \%) & \\
\hline Poor & $11(16.9 \%)$ & $129(8.6 \%)$ & $140(8.9 \%)$ & \\
\hline
\end{tabular}

hard tissue anomalies who had caries $(p=0.70)$. However, significantly more children with developmental dental hard tissue anomalies had poor oral hygiene $(p=0.03)$ when compared with children who did not have developmental dental hard tissue anomalies.

Table 2 shows the prevalence of each dental anomaly and the distribution by gender and socioeconomic class. The most prevalent developmental dental hard tissue anomaly found in the study population was enamel hypoplasia $(54.0 \%)$. Other lesions identified were microdontia (40.0\%), fusion/gemination (1.5\%), dens evaginatus $(1.5 \%)$, dens invaginatus $(1.5 \%)$ and talons cusp $(0.06 \%)$. Significantly more females $(63.1 \%)$ than males $(36.9 \%)$ had enamel hypoplasia $(p=0.003)$. Also, significantly more children with middle $(49.2 \%)$ socioeconomic class had enamel hypoplasia when compared with children with low (32.3\%) and high (18.5\%) socioeconomic class $(p=0.001)$.

Table 2 Dental anomalies by sex and socio-economic status $(N=65)$

\begin{tabular}{|c|c|c|c|c|c|c|}
\hline Dental hard-tissue anomaly & $\begin{array}{l}\text { Number of cases } \\
\text { affecting Male } \\
n=24\end{array}$ & $\begin{array}{l}\text { Number of cases } \\
\text { affecting Female } \\
n=41\end{array}$ & $\begin{array}{l}\text { Number of cases } \\
\text { affecting Low SES } \\
n=21\end{array}$ & $\begin{array}{l}\text { Number of cases } \\
\text { affecting Middle SES } \\
n=32\end{array}$ & $\begin{array}{l}\text { Number of cases } \\
\text { affecting High SES } \\
n=12\end{array}$ & $\begin{array}{l}\text { Prevalence of } \\
\text { lesion } N=65\end{array}$ \\
\hline Enamel hypoplasia & $11(45.8 \%)$ & $24(58.6 \%)$ & $11(52.4 \%)$ & $15(46.9 \%)$ & $9(75.0 \%)$ & $35(54.0 \%)$ \\
\hline Microdontia & $12(50.0 \%)$ & 14 (34.2 \%) & $9(42.9 \%)$ & $14(43.8 \%)$ & $3(25.0 \%)$ & $26(40.0 \%)$ \\
\hline Dens Evaginatus & $0(0.0 \%)$ & $1(2.4 \%)$ & $0(0.0 \%)$ & $1(3.1 \%)$ & $0(0.0 \%)$ & $1(1.5 \%)$ \\
\hline Fusion/germination & 0 (0.0 \%) & $1(2.4 \%)$ & $0(0.0 \%)$ & 1 (3.1\%) & $0(0.0 \%)$ & $1(1.5 \%)$ \\
\hline Talon cusp & 1 (4.2\%) & $0(0.0 \%)$ & 1 (4.7\%) & $0(0.0 \%)$ & $0(0.0 \%)$ & $1(1.5 \%)$ \\
\hline Dens invaginatus & 0 (0.0 \%) & $1(2.4 \%)$ & 0 (0.0\%) & 1 (3.1\%) & $0(0.0 \%)$ & $1(1.5 \%)$ \\
\hline Macrodontia & 0 (0.0 \%) & $0(0.0 \%)$ & $0(0.0 \%)$ & 0 (0.0 \%) & $0(0.0 \%)$ & $0(0.0 \%)$ \\
\hline Supernumerary & 0 (0.0 \%) & $0(0.0 \%)$ & $0(0.0 \%)$ & 0 (0.0 \%) & $0(0.0 \%)$ & $0(0.0 \%)$ \\
\hline Transposition & $0(0.0 \%)$ & $0(0.0 \%)$ & $0(0.0 \%)$ & 0 (0.0 \%) & $0(0.0 \%)$ & $0(0.0 \%)$ \\
\hline Notch incisor & 0 (0.0\%) & $0(0.0 \%)$ & 0 (0.0\%) & $0(0.0 \%)$ & $0(0.0 \%)$ & $0(0.0 \%)$ \\
\hline Hypodontia & $0(0.0 \%)$ & $0(0.0 \%)$ & $0(0.0 \%)$ & $0(0.0 \%)$ & $0(0.0 \%)$ & $0(0.0 \%)$ \\
\hline Total & $24(100.0)$ & $41(100.0)$ & $21(100.0)$ & $32(100.0)$ & $12(100.0)$ & 65 (100.0) \\
\hline
\end{tabular}


Table 3 highlights the proportion of children with developmental dental hard tissue anomalies by their caries and oral hygiene status. The proportion of children who had enamel hypoplasia $(p=0.43)$ and microdontia $(p=0.53)$ who also had caries were not significantly more than those children who had the developmental dental hard anomalies and did not have caries. Likewise, the proportion of children with enamel hypoplasia who had good, fair and poor oral hygiene was not significantly different $(p=0.36)$. However, more children with microdontia had fair oral hygiene compared with children with microdontia who had good and poor oral hygiene $(p=0.01)$.

Table 4 highlights the odds of having caries and poor oral hygiene in children with developmental dental hard tissue anomalies adjusting for the effect of age, sex and socioeconomic class, caries and poor oral hygiene. Caries could increase the risk for poor oral hygiene [33] and poor oral hygiene could increase the risk for caries: [34, 35]. Age, sex and socioeconomic status are risk factors for caries [36-38] and poor oral hygiene [39, 40]. It was therefore important to adjust for these possible confounders in this regression model.

Children with developmental dental hard tissue anomalies had significantly increased probability of having poor oral hygiene when compared with children who did not have developmental dental hard tissue anomalies (APR: $0.07 ; 95$ \% CI: $0.03-0.12 ; p=0.002$ ). Children with developmental dental hard tissue anomalies had insignificantly increased probability of having caries when compared with children who did not have developmental dental hard tissue anomalies (APR: 0.005; 95 \% CI: $-0.03-0.04$; $p=0.077)$.

\section{Discussion}

This study contributes to body of literature on the prevalence of developmental dental anomalies in the permanent dentition. The study found that the prevalence of developmental dental hard tissue anomalies in the study populations was low, there was no sex, age or socio-economic differences in the prevalence of developmental dental hard tissue anomalies in the permanent dentition of children and there was no significant association between the presence of developmental dental hard tissue anomalies and dental caries. There was however, a significant association between the presence of developmental dental hard tissue anomalies and oral hygiene status; more children with developmental dental hard tissue anomalies were likely to have poor oral hygiene. Also, more female children and more children with middle socioeconomic status were likely to have enamel hypoplasia.

The study has a few limitations. First, while we studied 11 different developmental dental hard tissue anomalies, only six lesions (enamel hypoplasia, microdontia, dens evaginatus, fusion/germination, Talon cusp and dens invaginatus) were identified in the study population. Of these $93.8 \%$ of the lesion were enamel hypoplasia and microdontia. The study findings may therefore bear more relevance to these two lesions than the entire range of developmental dental hard tissue anomalies. Second, the diagnosis of microdontia and macrodontia was based on visual examination and not by measuring the dimensions of the teeth using casts thus increasing the potential to introduce bias. Third, the assessment of caries was based on the WHO criteria. This implies that the number of teeth with caries detected in this study would be lower than the true prevalence since early enamel caries would not be detected. Fourth, though the field workers were experienced dentists who had practiced for many years in the field of paediatric dentistry, not conducting intra- and inter-examiner reliability increases the risk for disparity in diagnosis of lesion. We however feel that the disparity cannot be large enough to cause significant differences in findings of the examiners on the field since the examiners were all trained in the same institution by the same senior consultant, and had conducted multiple oral health surveys as a team in the past.

Despite these limitations, this study provides further evidence about risk factors for caries in the study environment. Prior studies have shown that the caries prevalence in the study population was low [32, 41, 42]

Table 3 Developmental dental hard tissue anomalies by caries and oral hygiene status $(N=65)$

\begin{tabular}{|c|c|c|c|c|c|c|}
\hline $\begin{array}{l}\text { Dental hard-tissue } \\
\text { anomaly }\end{array}$ & $\begin{array}{l}\text { Number of cases } \\
\text { with caries } n=8\end{array}$ & $\begin{array}{l}\text { Number of cases } \\
\text { without caries } \\
n=57\end{array}$ & $\begin{array}{l}\text { Number of cases with } \\
\text { good oral hygiene } \\
n=10\end{array}$ & $\begin{array}{l}\text { Number of cases with } \\
\text { fair oral hygiene } n=44\end{array}$ & $\begin{array}{l}\text { Number of cases with } \\
\text { poor oral hygiene } \\
n=11\end{array}$ & $\begin{array}{l}\text { Prevalence of } \\
\text { lesion }(N=65)\end{array}$ \\
\hline Enamel hypoplasia & $2(25.0 \%)$ & $33(57.8 \%)$ & $5(50.0 \%)$ & $26(59.1 \%)$ & $4(36.4 \%)$ & $35(54.0 \%)$ \\
\hline Microdontia & $4(50.0 \%)$ & $22(38.6 \%)$ & $4(40.0 \%)$ & $15(34.0 \%)$ & $7(63.6 \%)$ & $26(40.0 \%)$ \\
\hline Dens Evaginatus & 1 (12.5 \%) & $0(0.0 \%)$ & $0(0.0 \%)$ & $1(2.3 \%)$ & $0(0.0 \%)$ & $1(1.5 \%)$ \\
\hline Fusion/germination & $0(0.0 \%)$ & $1(1.8 \%)$ & $0(0.0 \%)$ & $1(2.3 \%)$ & $0(0.0 \%)$ & $1(1.5 \%)$ \\
\hline Talon cusp & $0(0.0 \%)$ & $1(1.8 \%)$ & 1 (10.0\%) & $0(0.0 \%)$ & $0(0.0 \%)$ & $1(1.5 \%)$ \\
\hline Dens Invaginatus & 1 (12.5 \%) & $0(0.0 \%)$ & $0(0.0 \%)$ & $1(2.3 \%)$ & $0(0.0 \%)$ & I (1.5 \%) \\
\hline Total & 8 (100.0 \%) & 57 (100.0\%) & $10(100.0)$ & 44 (100.0 \%) & $11(100.0 \%)$ & 654 (100.0\%) \\
\hline
\end{tabular}


Table 4 Multivariate analysis of factors associated with presence of developmental dental hard tissue anomalies $(N=1565)$

\begin{tabular}{|c|c|c|c|c|}
\hline Variables & Adjusted Prevalence Ratio (APR) & Std. Err. & $P$ value & $95 \%$ Conf. Interval \\
\hline \multicolumn{5}{|l|}{ Oral hygiene status } \\
\hline Good oral hygiene status & 1.00 & - & - & - \\
\hline Fair oral hygiene status & 0.02 & 0.02 & 0.14 & $-0.007-0.05$ \\
\hline Poor oral hygiene status & 0.07 & 0.03 & 0.002 & $0.03-0.12$ \\
\hline \multicolumn{5}{|l|}{ Caries status } \\
\hline Absence of caries & 1.00 & - & - & - \\
\hline Presence of caries & 0.005 & 0.02 & 0.77 & $-0.03-0.04$ \\
\hline \multicolumn{5}{|l|}{ Gender } \\
\hline Male & 1.00 & - & - & - \\
\hline Female & -0.006 & 0.01 & 0.64 & $-0.03-0.02$ \\
\hline \multicolumn{5}{|l|}{ Socioeconomic status } \\
\hline High socioeconomic class & 1.00 & - & - & - \\
\hline Middle socioeconomic class & -0.001 & 0.02 & 0.95 & $-0.03-0.03$ \\
\hline Low socioeconomic class & -0.007 & 0.02 & 0.68 & $-0.04-0.03$ \\
\hline
\end{tabular}

and even lower than the caries prevalence in many other developing and developed countries. The risk and protective factors for caries in the study environment are also not well understood [32]. This study provides evidence that the presence of developmental dental hard tissue anomalies does not increase the probability of children having caries in the study population.

Of importance is the significant association between developmental dental hard tissue anomalies and poor oral hygiene. The presence of dental hard tissue anomalies increases difficulty in tooth cleaning [22]. It also increases malocclusion, which also increases the risk for plaque retention and poor oral hygiene $[42,43]$. The finding of this study is therefore consistent with prior observations $[44,45]$ and has programmatic implications for managing adolescents. Adolescents with developmental dental hard tissue anomaly should be treated as having high risk for poor oral hygiene and should therefore be recalled more frequently for dental visits with particular emphasis on educating them about oral toileting including possible use of adjunctive therapies. This is important as oral health affect adolescents perception of body image, self-esteem and mental health [46, 47].

This study found a non-significant association between caries and presence of enamel hypoplasia unlike the findings of some previous studies [48-51]. While VargasFerreira et al's [51] meta-analysis strongly indicates that developmental defects of the enamel such as enamel hypoplasia is a risk factor for caries, this study finding indicates that enamel hypoplasia is not a risk factor for caries in the study population from a sub-urban developing country where the caries prevalence and severity is low [52]. However, the non-significant association between developmental dental hard tissue anomalies and caries and the significant association between developmental dental hard tissue anomalies and poor oral hygiene may highlight the probable pathophysiology of caries associated with developmental dental hard tissue anomalies: caries results as a secondary outcome of poor oral hygiene and not through a direct pathway. This postulation would need further studies, as there are multiple inter-related factors that may increase the susceptibility of teeth with developmental dental hard tissue anomalies to caries.

The study finding on gender and socioeconomic class differences in the prevalence of enamel hypoplasia differed from the findings of Robles et al. [53] in Spain who showed increased prevalence increased prevalence of developmental defects of the enamel (inclusive of enamel hypoplasia) in males and in children from middle and low socioeconomic status. The increasing risk for developmental defects of the enamel with decreasing socioeconomic status had been established, with this association linked to poor nutritional status [54]. However, the differences in the prevalence of developmental defects of the enamel by gender remains unclear with authors identifying male at greater risks $[55,56]$, some identifying females at increased risk [57, 58] while others show no gender association [59,60]. Many of these studies assessed enamel defects, regardless of whether it was opacity or hypoplasia.

This study was a school based study implying that children in Southwestern Nigeria who do not attend school have been left out of this survey as reports show that a high proportion of children in Nigeria are out of school [61]. This limits the generalizability of the study finding. However, within the limits of the design of the study, the data still provides useful information highlighting the prevalence of developmental dental hard tissue 
anomalies in the permanent dentition in the study population, and the non-significant association between developmental dental hard tissue anomalies generally and enamel hypoplasia specifically, with caries in the study population.

\section{Conclusions}

Children in Southwestern Nigeria have low clinical prevalence of developmental dental hard tissue anomalies in their permanent dentition. More females and children with middle socioeconomic status had enamel hypoplasia. The presence of developmental dental hard tissue anomalies is significantly associated with poor oral hygiene but not caries in the study population. Children with developmental dental hard tissue anomalies should be treated as children with high risk for poor oral hygiene.

\section{Abbreviations}

APR, adjusted prevalence ratio; DMFT, decayed, filled and missing permanent teeth; ECC, early childhood caries; LGA, Local Government Area; OHI - S, oral hygiene index status; PR, prevalence ratio; WHO, World Health Organization

\section{Acknowledgement}

The authors acknowledge Dr Ifesanya Joy for her contribution in data collection in her institution.

\section{Funding}

There was no funding support available for this study. Funding was by personal contribution of the authors.

\section{Availability of data and materials}

All data sets on which the conclusions of the paper rely are presented in the main papers.

\section{Authors' contributions \\ MOF conceptualized the study and conducted the data analysis, interpretation of data, developed the draft and managed the revision of manuscript. BOP and MO contributed to the design of the study, acquisition of data and drafting and revising of manuscript. All authors read the final and approved the final version of the manuscript.}

\section{Competing interests}

The authors declare that they have no competing interests.

\section{Consent for publication}

Written informed consent was obtained from a parent or legal guardian of each study participant prior to enrollment, and assent was also sought from all study participants. Only children who agreed to participate were enrolled in the study.

\section{Ethics approval and consent to participate}

Before commencement of the study, ethical approval was obtained from the Obafemi Awolowo University Teaching Hospital Complex lle-lfe (ERC2013/12/8) and Oyo State Ministry of Health Ethics Review Boards (AD 13/479/493). Approval for community entry was obtained from the LGA offices. All examinations were performed in the students' classroom with a teacher present. To ensure privacy, a corner was created in each classroom for the conduct of the clinical examination. All children who needed oral health care were provided with referral letters. All patients that required oral health care were provided with referral letters and informed about access to free oral health care in the health institution of the study investigators. No financial incentive was given for study participation.

\section{Author details}

${ }^{1}$ Department of Child Oral Health, College of Medicine, University of Ibadan, Oyo State, Nigeria. ${ }^{2}$ Department of Child Dental Health, Obafemi Awolowo
University Teaching Hospitals Complex, Ile-Ife, Nigeria. ${ }^{3}$ Department of Child Dental Health, Obafemi Awolowo University, lle-Ife, Nigeria. ${ }^{4}$ Department of Child Oral Health, Faculty of Dentistry, College of Medicine, University of Ibadan, Oyo State, Nigeria.

Received: 3 December 2015 Accepted: 11 June 2016

Published online: 07 July 2016

References

1. Patil S, Doni B, Kaswan S, Rahman F. Prevalence of dental anomalies in Indian population. J Clin Exp Dent. 2013:5:e183-6.

2. Gupta SK, Saxena P, Jain S, Jain D. Prevalence and distribution of selected developmental dental anomalies in an Indian population. J Oral Sci. 2011;53:231-8.

3. Afify $\mathrm{AR}$, Zawawi $\mathrm{KH}$. The prevalence of dental anomalies in the Western region of Saudi Arabia. ISRN Dent. 2012;2012:837270.

4. Altug-Atac AT, Erdem D. Prevalence and distribution of dental anomalies in orthodontic patients. Am J Orthod Dentofacial Orthop. 2007;131:510-4.

5. Haugland L, Storesund T, Vandevska-Radunovic V. Prevalence of dental anomalies in Norwegian school children. Open J Stomatol. 2013;3:329-33.

6. Orenuga OO, Odukoya O. An epidemiological study of developmental defects of enamel in a group of Nigerian school children. Pesq Bras Odontoped Clin Integr João Pessoa. 2010;10:385-91.

7. Temilola DO, Folayan MO, Fatusi OA, et al. The prevalence, pattern and clinical presentation of developmental dental hard-tissue anomalies in children with primary and mix dentition from Ile-lfe, Nigeria. BMC Oral Health. 2014;14:125

8. Basdra EK, Kiokpasoglou MN, Komposch G. Congenital tooth anomalies and malocclusions: a genetic link? Eur J Orthod. 2001;23:145-51.

9. Grošelj M, Jan J. Molar incisor hypomineralisation and dental caries among children in Slovenia. Eur J Paediatr Dent. 2013:14:241-5.

10. Hou GL, Lin CC, Tsai CC. Ectopic supernumerary teeth as a predisposing cause in localized periodontitis. Case report. Aust Dent J. 1995:40:226-8.

11. Guttal KS, Naikmasur VG, Bhargava P, Bathi RJ. Frequency of developmental dental anomalies in the Indian population. Eur J Dent. 2010;4:263-9.

12. Yassin OM, Rihani FB. Multiple developmental dental anomalies and hypermobility type Ehlers-Danlos syndrome. J Clin Pediatr Dent. 2006;30:337-41.

13. Dressler S, Meyer-Marcotty P, Weisschuh N, Jablonski-Momeni A, Pieper K, Gramer G, Gramer E. Dental and craniofacial anomalies associated with Axenfeld-Rieger syndrome with PITX2 mutation. Case Rep Med. 2010;2010:621984.

14. Yadak PV, Saha S, Jaqannath GV, Singh S. Prevalence and association of developmental defects of enamel with dental caries and nutritional status in preschool children. J Clin Diagn Res. 2015;9(10):32-40.

15. Opydo- Szymaczek J, Gerreth K. Developmental enamel defects of the permanent first molars and incisors and their association with dental caries in the region of Wielkopolska, Western Poland. Oral Health Prev Dent. 2015:13(5):461-9.

16. Hong L, Levy SM, Warren JJ, Broffit B. Association between enamel hypoplasia and dental caries in primary second molars: A cohort study. Caries Res. 2009;43(5):345-53.

17. Parolia A, Kundabala M, Dahal M, Mohan M, Thomas MS. Management of supernumerary teeth. J Conserv Dent. 2011;14(3):221-4.

18. Alberti G, Mondani PM, Parodi V. Eruption of supernumerary permanent teeth in a sample of urban primary school population in Genoa, Italy. Eur J Paediatr Dent. 2006;7(2):89-92.

19. Gaikwad SS, Gheware A, Kamatagi L, Pasumarthy S, Pawar V, Fatagare M. Dental Caries and its Relationship to Malocclusion in Permanent Dentition Among 12-15 Year Old School Going Children. J Int Oral Health. 2014;6(5):27-30.

20. Mtaya M, Brudvik P, Astrom NA. Prevalence of malocclusion and its relationship with sociodemographic factors, dental caries and oral hygiene in 12 to 14 year old Tanzanian school children. Eur J Ortho. 2009;31:467-76.

21. Oyedele TA, Folayan MO, Adekoya-Sofowora CA, Oziegbe EO. Co-morbidities associated with molar incisor hypomineraluzation in 8 to 16 year old pupils in Ile-Ife Nigeria. BMC Oral Health. 2015;15:37.

22. Folayan MO, Khami MR, Popoola BO, Onyejaka N, Adeyemo YI. Preventive oral health practices of school pupils in Southern Nigeria. BMC Oral Health. 2014;14:83.

23. Folayan MO, Chukwumah NM, Onyejaka N, Adeniyi AA, Olatosi OO. Appraisal of national response to the caries epidemic in children in Nigeria. BMC Oral Health. 2014;14:76. 
24. Kolawole KA, Folayan MO, Agbaje HO, et al. Digit Sucking Habit and Association with Dental Caries and Oral Hygiene Status of Children Aged 6 Months to 12 Years Resident in Semi-Urban Nigeria. PLoS ONE. 2016;11(2):e0148322.

25. Oziegbe EO, Esan TA, Oyedele TA. Brief communication: Emergence chronology of permanent teeth in Nigerian children. Am J Phys Anthropol. 2014;153(3):506-11.

26. Araoye MO. Research methodology with statistics for health and social science. Ilorin: Nathadex Publisher; 2003.

27. Olusanya O, Okpere O, Ezimokhai M. The importance of social class in voluntary fertility control in developing country. West Afr J Med. 1985:4:205-12.

28. Blishen BR. Indices of social classification. In: Robert K. Merton $\left(2^{\text {nd }}\right)$. Social stratification- a comparative analysis of structure and process. New York: Harcourt Brace; 1957. p. 78-185.

29. World Health Organisation. Oral Health Surveys: basic Methods. Geneva: World Health Organisation; 1997.

30. Krapp K. Dental Indices. Encyclopedia of Nursing \& Allied Health. Ed. Vol. 2. Gale Cengage. e Notes.com. retrieved $13^{\text {th }}$ March 2015 from: http://www.enotes.com/dental-indices-reference/.2002. Accessed 13 Mar 2015.

31. Greene JC, Vermillion JR. The simplified oral hygiene index. J Am Dent Assoc. 1964;68:7-13.

32. Folayan $\mathrm{MO}$, Idehen $\mathrm{EE}$, Ufomata $\mathrm{D}$. The effect of sociodemographic factors on dental anxiety in children seen in a suburban Nigerian hospital. Int J Paediatr Dent. 2003;13:20-6.

33. Kovacs $V$, Tihanyi D, Gera I. The incidence of local plaque retentive factors in chronic periodontitis. Foqorv SZ. 2007;100(6):295-300.

34. Ayele FA, Taye BW, Ayele TA, Gelaye KA. Predictors of dental caries among children 7-14 years in North West Ethiopia: a community based cross-sectional study. BMC Oral Health. 2013;13:7.

35. Sowole A, Sote E, Folayan M. Dental caries, pattern and predisposing oral hygiene related factors in Nigerian preschool children. Eur Arch Paediatr Dent. 2007:8(4):206-10.

36. Sofola $\mathrm{OO}$, Folayan $\mathrm{MO}$, Oginni $\mathrm{AB}$. Changes in the prevalence of denta caries n primary school children in Lagos State, Nigeria. Nig J Clin Prac. 2014;17(2):127-33

37. Ur Rehman MM, Mahmood N, Ur RB. The relationship of caries with oral hygiene status and extraoral risk factors. Ayub Med Coll Abottab. 2008;20(1):103-8

38. Mahfouz M, Esaid AA. Dental caries prevalence among 12 to 15 years old Palestanian children. Inter Schorlar Res Notices. 2014. doi:10.1155/2014/785404.

39. Taani DR. Relationship of socioeconomic status background to oral hygiene, gingival status and caries in children. Quintessence Int. 2002;33(3):195-8.

40. Ogunsile SE, Ojo I. Oral hygiene status of adolescents in a local government area of Oyo State, Nigeria. J Sci Technol. 2010;30(3):81-6.

41. Folayan MO, Adeniyi AA, Chukumah $\mathrm{N}$, et al. Programme guidelines for promoting good oral health for children in Nigeria: a position paper. BMC Oral Health. 2014;14:128.

42. Ranganath $V$, Ashish SN, Soumya V. Amelogenesis Imperfecta: A challenge to restoring esthetics and function. J Inian Soc. Periodontol. 2010;14(3):195-197.

43. Hattab FN, Hazzaá AM. An unusual case of talon cusp on geminated tooth. J Can Dent Assoc. 2001:67:263-7.

44. Sarraf-Shirazi A, Rezaiefar M, Forghani M. A rare case of multiple Talon cusps in three siblings. Braz Dent J. 2010:21(5):463-466.

45. Uslu O, Akcam MO, Evirgen S, Cebeci I. Prevalence of dental anomalies in various malocclusions. Am J Orthod Dentofacial Orthop. 2009:135:328-35.

46. Hashem A, Kelly A, O'Connell B, O'Sullivan M. Impact of moderate and severe hypodontia and amelogenesis imperfecta on quality of life and self-esteem of adult patients. J Dent. 2013;41:689-94.

47. Trentesaux T, Rousset MM, Dehaynin E, Laumaillé M, Delfosse C. 15-year follow-up of a case of amelogenesis imperfecta: Importance of psychological aspect and impact on quality of life. Eur Arch Paediatr Dent. 2013;14:47-51.

48. Cruvinel VR, Gravina DB, Azevedo TD, Bezerra AC, Toledo AO. Prevalence of dental caries and caries-related risk factors in premature and term children. Braz Oral Res. 2010;24(3):329-35.

49. Horowitz HS. Research issues in early childhood caries. Community Dent Oral Epidemiol. 1998;26 Suppl 1:67-8.

50. Fotedar S, Sogi GM, Sharma KR. Enamel hypoplasia and its correlation with dental caries in 12 and 15 years old school children in Shimla, India. J Indian Assoc public Health Dent. 2014;12:18-22.
51. Vargas-Ferreira F, Salas MM, Nascimento GG, et al. Association between developmental defects of enamel and dental caries: A systematic review and meta-analysis. J Dent. 2015;43(6):619-28.

52. Petersen PE. Challenges to improvement of oral health in the $21 \mathrm{st}$ century - the approach of the WHO Global Oral Health Programme. Int Dent J. 2004;54:329-43.

53. Robles MJ, Ruiz M, Bravo-Perez M, González E, Peñalver MA. Prevalence of enamel defects in primary and permanent teeth in a group of schoolchildren from Granada (Spain). Med Oral Patol Oral Cir Bucal. 2013;18(2):e187-93.

54. Ford D, Seow WK, Kazoullis S, Holcombe T, Newman B. A controlled study of risk factors for enamel hypoplasia in the permanent teeth. Pediatr Dent. 2009;31:382-8

55. Li Y, Navia JM, Bian JY. Prevalence and distribution of developmental enamel defects in the primary dentition of Chinese children 3-5 years old. Community Dent Oral Epidemiol. 1995:23:72-9.

56. Farsi N. Developmental enamel defects and their association with dental caries in preschoolers in Jeddah, Saudi Arabia. Oral Health Prev Dent. 2010;8:85-92.

57. King T, Humphrey LT, Hillson S. Linear enamel hypoplasias as indicators of systemic physiological stress: evidence from two known age-at-death and sex populations from postmedieval London. Am J Phys Anthropol. 2005:128(3):547-59.

58. Griffin RC, Donlon D. Patterns in dental enamel hypoplasia by sex and age at death in two archaeological populations. Arch Oral Biol. 2009;54 Suppl 1:S93-100.

59. Zagdwon AM, Toumba KJ, Curzon ME. The prevalence of developmental enamel defects in permanent molars in a group of English school children. Eur J Paediatr Dent. 2002;3(2):91-6.

60. de Liefde B, Herbison GP. Prevalence of developmental defects of enamel and dental caries in New Zealand children receiving differing fluoride supplementation. Community Dent Oral Epidemiol. 1985;13(3):164-7.

61. National Bureau of Statistics. 2006 population census. Internet: http://www. nigerianstat.gov.ng/Connections/Pop2006.pdf. Accessed 4 July 2015.

\section{Submit your next manuscript to BioMed Central and we will help you at every step:}

- We accept pre-submission inquiries

- Our selector tool helps you to find the most relevant journal

- We provide round the clock customer support

- Convenient online submission

- Thorough peer review

- Inclusion in PubMed and all major indexing services

- Maximum visibility for your research

Submit your manuscript at www.biomedcentral.com/submit 